\title{
Cross-metathesis of vinylsilanes with olefins in the presence of Grubbs' catalyst
}

\author{
Cezary Pietraszuk, ${ }^{\mathrm{a}, \mathrm{b}}$ Helmut Fischer, ${ }^{\mathrm{b}}$ Małgorzata Kujawa ${ }^{\mathrm{a}}$ and Bogdan Marciniec ${ }^{\mathrm{a}, *}$ \\ ${ }^{a}$ Faculty of Chemistry, Adam Mickiewicz University, 60-780 Poznań, Poland \\ ${ }^{\mathrm{b}}$ Fachbereich Chemie, Universität Konstanz, Fach M 727, 78457 Konstanz, Germany
}

Received 18 September 2000; revised 2 November 2000; accepted 29 November 2000

\begin{abstract}
Effective cross-metathesis of $\mathrm{H}_{2} \mathrm{C}=\mathrm{C}(\mathrm{H}) \mathrm{SiR}_{3}$, where $\mathrm{SiR}_{3}=\mathrm{Si}(\mathrm{OMe})_{3}, \mathrm{Si}(\mathrm{OEt})_{3}, \mathrm{Si}(\mathrm{OSiMe})_{3}$, with selected olefins in the presence of $\left(\mathrm{PCy}_{3}\right)_{2} \mathrm{Cl}_{2} \mathrm{Ru}(=\mathrm{CHPh})(\mathrm{I})$ is described. Treatment of $p$-substituted styrenes, 1 -alkenes and selected allyl derivatives $\mathrm{H}_{2} \mathrm{C}=\mathrm{CHCH}_{2} \mathrm{R}^{\prime}\left(\mathrm{R}^{\prime}=\mathrm{SiMe}_{3}, \mathrm{Si}(\mathrm{OEt})_{3}, \mathrm{Ph}, \mathrm{OPh}\right)$ with an excess of $\mathrm{H}_{2} \mathrm{C}=\mathrm{C}(\mathrm{H}) \mathrm{SiR}_{3}$ results in the formation of the respective cross-metathesis products with good yields and selectivities. The metallacarbene mechanism of the process is discussed. C 2001 Elsevier Science Ltd. All rights reserved.
\end{abstract}

Silyl olefins constitute an important class of compounds widely applied in organic synthesis. ${ }^{1}$ Numerous methods for their preparation have been reported. ${ }^{1 \mathrm{~b}, \mathrm{c}}$ Catalytic methods include the hydrosilylation of alkynes, the dehydrogenative silylation of alkenes and the hydrogenation of alkynylsilanes. ${ }^{1 \mathrm{c}}$ The catalytic silylation of olefins by vinylsilanes developed in our group is an effective and general method for the preparation of alkenylsilanes. ${ }^{2}$ The reaction, which resembles crossmetathesis, however, proceeds by a non-metallocarbene mechanism involving activation of $\mathrm{C}-\mathrm{H}$ and $\mathrm{Si}-\mathrm{C}=$ bonds according to Scheme $1 .^{3}$

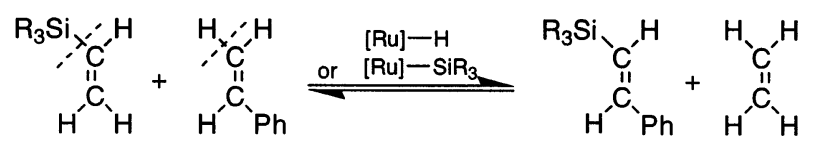

Scheme 1.

Unfortunately, the formation of some amounts of isomerization products cannot be avoided when using this method. ${ }^{4}$

The development of well-defined, functional group tol-

* Corresponding author. erant ruthenium and molybdenum metathesis catalysts has opened new opportunities for applying metathesis in organic synthesis. ${ }^{5}$ Important progress has also been made in developing efficient and highly selective crossmetathesis systems. ${ }^{6}$

Recently, we reported on the high catalytic activity of Grubbs' catalyst in the cross-metathesis of vinylsilanes and vinylsiloxanes with styrene (Scheme 2). ${ }^{7}$ High yields and selectivities were obtained for vinyltrialkoxyand vinyltrisiloxysilanes under very mild conditions (room temp.).
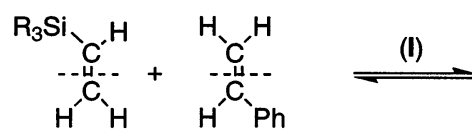

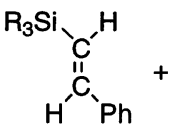<smiles>C=C</smiles>

Scheme 2.

In this paper we describe new examples of effective cross-metathesis of vinyltrialkoxy- and vinyltrisiloxysilanes with aryl-, alkyl-, and allyl-substituted olefins catalyzed by complex $\mathbf{I}^{8}$

The reactions proceeded according to Eq. (1): 


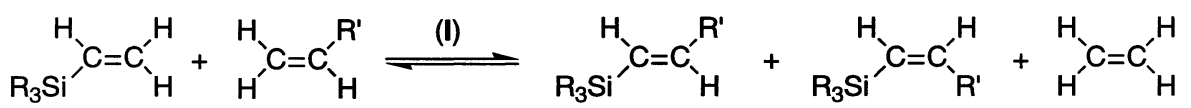

where: $\mathrm{SiR}_{3}=\mathrm{Si}(\mathrm{OMe})_{3}, \mathrm{Si}(\mathrm{OEt})_{3}, \mathrm{Si}\left(\mathrm{OSiMe}_{3}\right)_{3}$

$\mathrm{R}^{\prime}$ = alkyl, aryl,

Table 1. Cross-metathesis of vinylsilanes with selected olefins

\begin{tabular}{|c|c|c|c|c|c|}
\hline $\mathrm{H}_{2} \mathrm{C}=\mathrm{CHSiR}_{3}$ & Olefin & $\begin{array}{l}\text { Conversion of olefin } \\
\text { (vinylsilane) }{ }^{\mathrm{a}}[\%]\end{array}$ & $\begin{array}{l}\text { Yield of (isolated yield of) }(E+Z) \\
\mathrm{R}^{\prime} \mathrm{HC}=\mathrm{CHSiR}_{3}[\%]\end{array}$ & $E / Z$ & Yield of $\mathrm{R}^{\prime} \mathrm{HC}=\mathrm{CHR}^{\prime}[\%]$ \\
\hline $\mathrm{H}_{2} \mathrm{C}=\mathrm{CHSi}(\mathrm{OEt})_{3}$ & 4-Cl-Styrene & $72(100)^{\mathrm{a}}$ & $68,95^{\mathrm{a}},(85)^{\mathrm{a}}$ & $E$ & Traces \\
\hline $\mathrm{H}_{2} \mathrm{C}=\mathrm{CHSi}(\mathrm{OEt})_{3}$ & 4-Me-Styrene & $100^{\mathrm{b}}$ & $95^{\mathrm{b}}$ & $E$ & Traces \\
\hline $\mathrm{H}_{2} \mathrm{C}=\mathrm{CHSi}(\mathrm{OEt})_{3}$ & 4-OMe-styrene & $100^{\mathrm{b}}$ & $95^{\mathrm{b}}$ & $E$ & Traces \\
\hline $\mathrm{H}_{2} \mathrm{C}=\mathrm{CHSi}(\mathrm{OEt})_{3}$ & 1-Hexene & 100 & 75 & $9 / 1$ & 10 \\
\hline $\mathrm{H}_{2} \mathrm{C}=\mathrm{CHSi}(\mathrm{OEt})_{3}$ & 1-Decene & 75 & 60 & $10 / 1$ & 5 \\
\hline $\mathrm{H}_{2} \mathrm{C}=\mathrm{CHSi}(\mathrm{OEt})_{3}$ & Allyl-SiMe 3 & 100 & $95,(88)$ & $E$ & Traces \\
\hline $\mathrm{H}_{2} \mathrm{C}=\mathrm{CHSi}(\mathrm{OEt})_{3}$ & Allyl-Si(OEt) ${ }_{3}$ & 75 & 71 & $15 / 1$ & 0 \\
\hline $\mathrm{H}_{2} \mathrm{C}=\mathrm{CHSi}(\mathrm{OEt})_{3}$ & Allyl-Ph & 85 & 68 & $10 / 1$ & Traces \\
\hline $\mathrm{H}_{2} \mathrm{C}=\mathrm{CHSi}(\mathrm{OEt})_{3}$ & Allyl-OPh & 80 & 72 & $5 / 1$ & Traces \\
\hline
\end{tabular}

Reaction conditions: $\left[\left(\mathrm{PCy}_{3}\right)_{2} \mathrm{Cl}_{2} \mathrm{Ru}(=\mathrm{CHPh})\right]:\left[\mathrm{H}_{2} \mathrm{C}=\mathrm{CHSiR} 3\right]$ : $[$ olefin $]=5 \times 10^{-2}: 5: 1 ; \mathrm{CH}_{2} \mathrm{Cl}_{2}$, reflux, $3 \mathrm{~h}$.

${ }^{\mathrm{a}}[\mathrm{Ru}]:\left[\mathrm{H}_{2} \mathrm{C}=\mathrm{CHSiR}_{3}\right]:[$ olefin $]=5 \times 10^{-2}: 1: 3$.

b $1 \mathrm{~h}$.

The results obtained are summarized in Table $1 .{ }^{9}$ Products were isolated and characterized spectroscopically. ${ }^{10}$

Since vinylsilanes were found to be inactive for the conversion to self-metathesis products, ${ }^{7}$ the vinylsilanes could be used in excess. Thus, it was possible to minimize the role of competitive olefin self-metathesis. ${ }^{11}$ Efficient reactions were observed for $p$-substituted styrenes, 1-alkenes, phenyl-, phenoxy-, trimethylsilyl-, and triethoxysilyl-substituted allyl compounds. In contrast, no reaction was observed for allylamine, ${ }^{12}$ allylmethyl thioether ${ }^{13}$ and allyl chloride. In earlier studies these functional groups containing allyl derivatives were found to deactivate Grubbs' type carbene complexes. Vinylsilanes containing one or more methyl substituents at silicon gave only traces or no crossmetathesis products. Similar results were obtained in the reactions with styrene. ${ }^{7}$ Removal of ethylene was found to be crucial for an increase of reaction efficiency. ${ }^{7} \mathrm{~A}$ high metathesis conversion was achieved by effective stirring and heating of the reaction mixture in $\mathrm{CH}_{2} \mathrm{Cl}_{2}$ to a gentle reflux. All reactions proceeded highly stereoselectively with a strong preference for the formation of the $E$ isomer. The reactions of vinylsilanes with substituted styrenes ${ }^{7}$ as well as with the unsubstituted styrene and with allyltrimethylsilane even afforded exclusively (within detection limits) the $E$ isomer.

Based on the results of our earlier study, ${ }^{7}$ a metallacarbene mechanism for these cross-metathesis reactions is postulated (Scheme 3).

The benzylidene complex I reacts with vinylsilane to form the methylidene complex II and silylstyrene. ${ }^{7}$
Compound II then reacts with the olefin $\mathrm{H}_{2} \mathrm{C}=\mathrm{C}(\mathrm{H}) \mathrm{R}^{\prime}$ to give the alkenylidene complex III and ethylene. This reaction is a part of the commonly accepted metathesis mechanism. ${ }^{14}$ The competitive reaction of II with vinyltrialkoxy or vinyltrisiloxysilane leads to an exchange of methylidene units but does not produce the silylcarbene complex. ${ }^{7}$ By reaction of vinylsilane with III the cross-

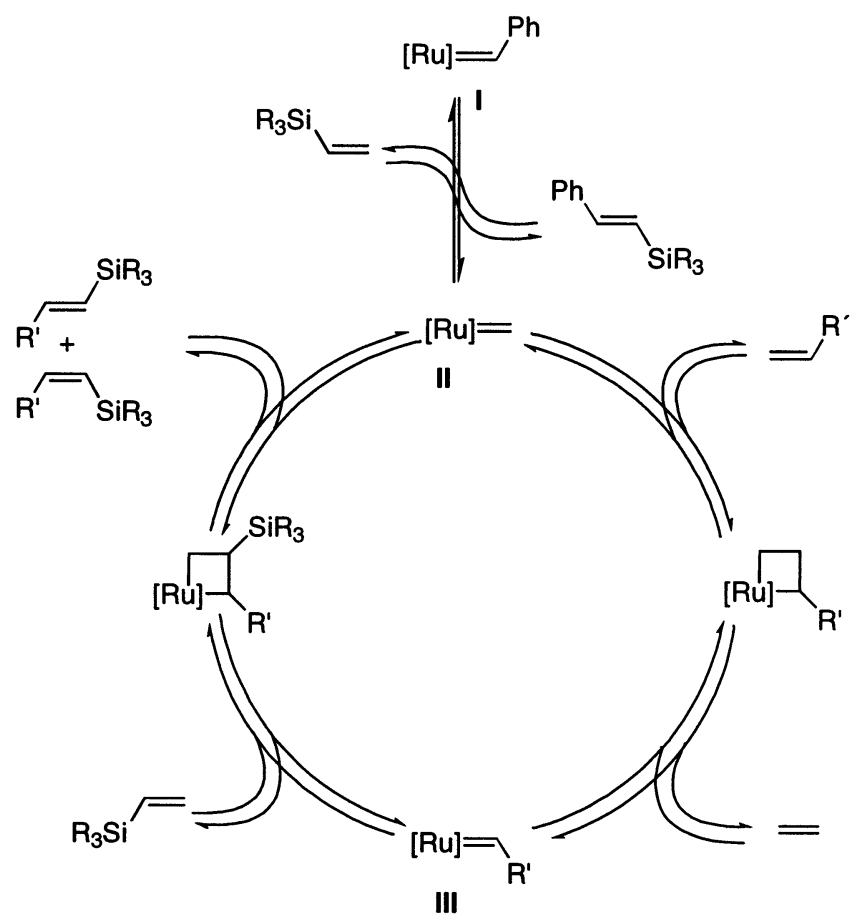

Scheme 3. Proposed catalytic cycle for the cross-metathesis of vinylsilanes with olefins. 
metathesis product is formed. The relatively high catalyst concentration that has to be used is a consequence of the instability of the methylidene complex II under the conditions used. ${ }^{15} \mathrm{~A}$ detailed analysis of the reaction mixture indicates that, in addition to crossmetathesis and olefin metathesis products, also minor amounts of silylstyrenes - and for the reactions of vinyltrialkoxysilane - traces of tetraalkoxysilane (alkyl orthosilicate) are produced. The formation of silylstyrenes (Scheme 3) in the reaction of vinylsilanes with $\mathbf{I}$ has been described earlier in more detail ${ }^{7}$ and confirms the mechanistic scheme proposed above. Traces of $\mathrm{Si}(\mathrm{OR})_{4}$ found in the reaction mixture are presumably formed by catalytic redistribution at silicon. ${ }^{16}$ Double-bond migration (olefin isomerization) was not observed in the starting olefins or in the cross-metathesis products. This confirms that, under the conditions used, hydride complexes are not generated in situ. Thus, cross-metathesis offers the advantage of avoiding olefin isomerization whereas in most other catalytic systems involving hydride catalysts isomerization is inevitable. The generation of $\mathrm{Ru}-\mathrm{H}$ complexes in systems containing initially catalyst $\mathbf{I}$ at temperatures $\geq 60^{\circ} \mathrm{C}$ was reported very recently. ${ }^{17}$

In conclusion, the efficient and selective cross-metathesis of vinyltrialkoxy- and trisiloxysilanes with $p$-substituted styrene-, 1-alkene-, and allyl-derivatives in the presence of $\left(\mathrm{PCy}_{3}\right)_{2} \mathrm{Cl}_{2} \mathrm{Ru}(=\mathrm{CHPh})(\mathbf{I})$ offers an interesting route to unsaturated organosilicon compounds. In addition, the successful reactions with $\mathrm{H}_{2} \mathrm{C}=\mathrm{C}(\mathrm{H}) \mathrm{Si}(\mathrm{OSiMe})_{3}$ demonstrate the potential of this process for modification of poly(vinyl)siloxanes.

\section{Acknowledgements}

C.P. acknowledges a research grant from the Alexander von Humboldt Foundation. This work was also supported by a grant no. T09A 13919 from the State Committee for Scientific Research (Poland).

\section{References}

1. (a) Chan, T. H.; Fleming, I. Synthesis 1979, 761-786; (b) Colvin, E. W. Silicon Reagents in Organic Synthesis; Academic: London, 1988; Chapter 3; (c) The Chemistry of Organosilicon Compounds; Patai, S.; Rappoport, Z., Eds.; Wiley: Chichester, 1998.

2. (a) Marciniec, B.; Rzejak, L.; Gulinski, J.; Foltynowicz, Z.; Urbaniak, W. J. Mol. Catal. A: Chem. 1988, 46, 329-340; (b) Foltynowicz, Z.; Marciniec, B. J. Organomet. Chem. 1989, 376, 15-20; (c) Foltynowicz, Z.; Marciniec, B.; Pietraszuk, C. J. Mol. Catal. A: Chem. 1991, 65, 113-125; (d) Marciniec, B.; Pietraszuk, C.; Foltynowicz, Z. J. Mol. Catal. A: Chem. 1992, 76, 307317; (e) Marciniec, B.; Pietraszuk, C. J. Organomet. Chem. 1993, 447, 163-166; (f) Marciniec, B.; Pietraszuk, C.; Foltynowicz, Z. J. Appl. Organomet. Chem. 1993, 7, 539-541.
3. Marciniec, B.; Pietraszuk, C. Organometallics 1997, 16, 4320-4326.

4. Foltynowicz, Z. Pol. J. Chem. 1993, 67, 1-7.

5. For recent reviews, see: (a) Ivin, K. J.; Mol, J. C. Olefin Metathesis and Metathesis Polymerization; Academic: San Diego, 1997; (b) Alkene Metathesis in Organic Synthesis; Fürstner, A., Ed.; Springer: Berlin, 1998; (c) Grubbs, R. H.; Chang, S. Tetrahedron 1998, 54, 44134450.

6. For recent reviews, see: (a) Gibson, S. E.; Keen, S. P. In Alkene Metathesis in Organic Synthesis; Fürstner, A., Ed.; Springer: Berlin, 1998; pp. 155-181; (b) Blechert, S. Pure Appl. Chem. 1999, 71, 1393-1399; (c) Roy, R.; Das, S. K. Chem. Commun. 2000, 519-529.

7. Pietraszuk, C.; Marciniec, B.; Fischer, H. Organometallics 2000, 19, 913-917.

8. While this manuscript was under preparation, another example of effective cross-metathesis of vinyltriethoxysilane with 5-hexen-1-yl acetate was reported, see: Chatterjee, A. K.; Morgan, J. P.; Scholl, M.; Grubbs, R. H. J. Am. Chem. Soc. 2000, 122, 3783-3784.

9. General procedure for the catalytic cross-metathesis An oven dried flask equipped with a condenser and a magnetic stirring bar was charged under argon with $\mathrm{CH}_{2} \mathrm{Cl}_{2}$ (5 ml), decane or dodecane (internal standard), vinylsilane (vinylsiloxane) $\left(3.14 \times 10^{-3} \mathrm{~mol}\right)$ and the respective olefin $\left(6.28 \times 10^{-4} \mathrm{~mol}\right)$. The reaction mixture was stirred and heated in a water bath to maintain a gentle reflux. Then ruthenium benzylidene complex $\mathbf{I}\left(3.14 \times 10^{-5}\right.$ mol) was added and the reaction was controlled by GC. Analyses were made before and 3 hours after the addition of the complex.

Representative procedure for the synthesis of alkenylsilanes The reaction was carried out as described above with catalyst, reagents and solvent in ten times greater amounts. No standard was added. Reaction time: $3 \mathrm{~h}$. Then solvent was removed under atmospheric pressure. The product was isolated by vacuum distillation with the use of an efficient column (yields are included in Table 1).

10. Spectroscopic data of the selected new products:

$\boldsymbol{E}$-(EtO) $)_{3} \mathbf{S i C H}=\mathbf{C}(\mathrm{H}) \mathrm{CH}_{2} \mathrm{SiMe}_{3}:{ }^{1} \mathrm{H}$ NMR $\left(\mathrm{CDCl}_{3}, \mathrm{ppm}\right.$, coupling constants in $\mathrm{Hz}), \delta: 0.00\left(\mathrm{~s}, 9 \mathrm{H}, \mathrm{SiMe}_{3}\right) ; 1.21(\mathrm{t}$, $\left.J=6.9,9 \mathrm{H}, 3 \times \mathrm{CH}_{3}\right) ; 1.69\left(\mathrm{dd}, J=8.0,1.4,2 \mathrm{H}, \mathrm{CH}_{2} \mathrm{Si}\right)$; 3.78 (q, $\left.J=6.9,6 \mathrm{H}, 3 \times \mathrm{SiOCH}_{2}\right) ; 5.19(\mathrm{dt}, J=18.7,1.4,1$ $\mathrm{H},=\mathrm{CHSi}), 6.41(\mathrm{dt}, J=18.7,8.0 \mathrm{~Hz}, 1 \mathrm{H},=\mathrm{CH}) .{ }^{13} \mathrm{C}$ NMR $\left(\mathrm{CDCl}_{3}, \mathrm{ppm}\right) \delta:-2.02\left(\mathrm{SiMe}_{3}\right) ; 18.21\left(\mathrm{CH}_{3}\right) ; 28.89$ $\left(\mathrm{CH}_{2} \mathrm{Si}\right) ; 58.27\left(\mathrm{OCH}_{2}\right) ; 116.75(=\mathrm{CHSi}) ; 151.02(=\mathrm{CH})$. MS, $m / z$ (\%): 73 (97), 79 (14), 119 (46), 133 (45), 135 (44), 143 (34), 158 (64), 159 (68), 163 (100), 187 (51), 207 (49), 232 (44), 233 (77), 261 (54), $276\left(\mathrm{M}^{+}, 51\right) ; \mathrm{M}^{+}$found $=$ 276.15656, calculated for $\mathrm{C}_{12} \mathrm{H}_{28} \mathrm{O}_{3} \mathrm{Si}_{2}=276.15771$.

$\boldsymbol{E}-\left(\mathrm{Me}_{3} \mathrm{SiO}\right)_{3} \mathbf{S i C H}=\mathbf{C}(\mathbf{H}) \mathbf{C}_{\mathbf{4}} \mathbf{H}_{\mathbf{9}}:{ }^{1} \mathrm{H}$ NMR $\left(\mathrm{CDCl}_{3}, \mathrm{ppm}\right.$, coupling constants in $\mathrm{Hz}), \delta: 0.10\left(\mathrm{~s}, 27 \mathrm{H}, \mathrm{SiMe}_{3}\right) ; 0.90$ $\left(\mathrm{t}, J=6.8,3 \mathrm{H}, \mathrm{CH}_{3}\right) ; 1.26-1.44\left(\mathrm{~m}, 4 \mathrm{H}, 2 \times \mathrm{CH}_{2}\right) ; 2.07-$ $2.14\left(\mathrm{~m}, 2 \mathrm{H}, \mathrm{CH}_{2}\right) ; 5.36(\mathrm{dt}, J=18.4,1.6,1 \mathrm{H},=\mathrm{CHSi})$; $6.20(\mathrm{dt}, J=18.4,6.3,1 \mathrm{H},=\mathrm{CH}) .{ }^{13} \mathrm{C} \mathrm{NMR}\left(\mathrm{CDCl}_{3}\right.$, ppm) $\delta: 1.74\left(\mathrm{SiMe}_{3}\right) ; 13.92\left(\mathrm{CH}_{3}\right) ; 22.21\left(\mathrm{CH}_{2}\right) ; 30.62$ $\left(\mathrm{CH}_{2}\right) ; 36.05\left(\mathrm{CH}_{2}\right) ; 123.79$ (=CHSi); $150.24(=\mathrm{CH}) . \mathrm{MS}$, $m / z$ (\%): 59 (8), 73 (100), 191 (8), 193 (24), 207 (45), 295 (14), 363 (23), $378\left(\mathrm{M}^{+}, 1\right)$.

$\boldsymbol{E}$-(EtO) $)_{3} \mathbf{S i C H}=\mathbf{C}(\mathbf{H}) \mathbf{C}_{\mathbf{6}} \mathbf{H}_{\mathbf{4}} \mathbf{C l}:{ }^{1} \mathrm{H} \quad \mathrm{NMR} \quad\left(\mathrm{CDCl}_{3}, \mathrm{ppm}\right.$, coupling constants in $\mathrm{Hz}), \delta: 1.26\left(\mathrm{t}, J=6.8,9 \mathrm{H}, \mathrm{CH}_{3}\right)$; $3.88\left(\mathrm{q}, J=6.8,6 \mathrm{H}, \mathrm{CH}_{2} \mathrm{O}\right) ; 6.14(\mathrm{~d}, J=19.2,1 \mathrm{H}$, 
$=\mathrm{CHSi}) ; 7.35(\mathrm{~d}, J=19.2,1 \mathrm{H},=\mathrm{CH}) ; 7.31-7.39(\mathrm{~m}, 4 \mathrm{H}$, $\left.\mathrm{C}_{6} \mathrm{H}_{4} \mathrm{Cl}\right) .{ }^{13} \mathrm{C}$ NMR $\left(\mathrm{CDCl}_{3}, \mathrm{ppm}\right) \delta: 18.2\left(\mathrm{CH}_{3}\right) ; 58.6$ $\left(\mathrm{CH}_{2} \mathrm{O}\right) ; 118.6 \quad(=\mathrm{CHSi}) ; 127.9, \quad 128.7, \quad 134.4,136.0$ $\left(\mathrm{C}_{6} \mathrm{H}_{4} \mathrm{Cl}\right) ; 147.6(=\mathrm{CH}) . \mathrm{MS}, \mathrm{m} / z$ (\%): 79 (16), 91 (8), 107 (10), 115 (11), 119 (34), 135 (11), 163 (100), 164 (11), 179 (2), 181 (1), 195 (1), 225 (2), 255 (0.3), 300 $\left(\mathrm{M}^{+}, 0.2\right) ; \quad \mathrm{M}^{+}$found $=300.09478$, calculated for $\mathrm{C}_{14} \mathrm{H}_{21} \mathrm{ClO}_{3} \mathrm{Si}=300.09485$

11. A good yield to selectivity balance was obtained for a fivefold excess of vinylsilane. Larger excesses such as 10:1 result in a complete elimination of olefin selfmetathesis product but also slow down the rate of cross-metathesis. Different results were obtained for styrene and 4-chlorostyrene for which better yields (with no drop of selectivity) were obtained for [vinylsilane]:[styrene] $=1: 3$.
12. Fu, G. C.; Nguyen, S. B.; Grubbs, R. H. J. Am. Chem. Soc. 1993, 115, 9856-9857.

13. (a) Armstrong, S. K.; Christie, B. A. Tetrahedron Lett. 1996, 37, 9373-9376; (b) Shon, Y.-S.; Lee, T. R. Tetrahedron Lett. 1997, 38, 1283-1286.

14. For the mechanism of olefin metathesis, see: (a) Herisson, J. L.; Chauvin, Y. Makromol. Chem. 1971, 141, 161. The mechanism for ruthenium carbene complexes is discussed in: (b) Dias, E. L.; Nguyen, S. B.; Grubbs, R. H. J. Am. Chem. Soc. 1997, 119, 3887-3897.

15. Ulman, M.; Grubbs, R. H. J. Org. Chem. 1999, 64, 7202-7207.

16. Curtis, M. D.; Epstein, P. S. Adv. Organomet. Chem. 1981, 19, 213.

17. Marciniec, B.; Kujawa, M.; Pietraszuk, C. New J. Chem. 2000, 24, 671-675. 